\title{
Penerapan Model Pembelajaran Creative Problem Solving dengan Media Powerpoint Guna Meningkatkan Prestasi Belajar Agama Hindu
}

\author{
Ni Putu Warningsih ${ }^{1}$ \\ 1SMP Negeri 2 Gianyar, \\ Gianyar, Indonesia \\ email: niputuwarningsih@gmail.com
}

\begin{abstract}
Abstrak
Penelitian ini dilaksanakan di SMP Negeri 2 Gianyar di kelas VII G yang kemampuan siswanya untuk mata pelajaran Agama Hindu masih sangat rendah. Tujuan penulisan penelitian tindakan kelas ini adalah untuk meningkatkan prestasi belajar Agama Hindu siswa kelas VII G di SMP Negeri 2 Gianyar pada semester II tahun pelajaran 2018/2019 melalui penerapan model pembelajaran Creative Problem Solving dengan media powerpoint. Metode pengumpulan datanya adalah observasi dan tes prestasi belajar. Metode analisis datanya adalah deskriptif. Dengan hasil yang diperoleh dari penelitian ini adalah model pembelajaran yang diterapkan dapat meningkatkan prestasi belajar siswa. Ini terbukti dari hasil yang diperoleh pada awalnya hanya mencapai rata-rata 68,05 dan ketuntasan belajar $30,55 \%$, pada siklus I meningkat menjadi 74,86 dengan ketuntasan belajar $72,22 \%$ dan pada Siklus II meningkat menjadi 81,94 dengan ketuntasan belajar mencapai $100 \%$. Kesimpulan yang diperoleh dari penelitian ini adalah penerapan model pembelajaran Creative Problem Solving dengan media powerpoint dapat meningkatkan prestasi belajar Agama Hindu siswa kelas VII G SMP Negeri 2 Gianyar pada semester II tahun pelajaran 2018/2019.
\end{abstract}

Kata Kunci: Model Pembelajaran Creative Problem Solving, Media Powerpoint, Prestasi Belajar.

\begin{abstract}
This research was conducted at SMP Negeri 2 Gianyar in class VII G where the students' ability for Hinduism was still very low. The purpose of this classroom action research is to improve the learning achievement of Hindu students of class VII G at SMP Negeri 2 Gianyar in the second semester of the 2018/2019 academic year through the application of the Creative Problem Solving learning model with powerpoint media. The data learning method is observation and learning achievement test. The data analysis method is descriptive. With the results obtained from this study is the learning model that is applied to improve student achievement. It is evident from the results obtained initially only reached an average of 68.05 and $30.55 \%$ completeness in learning, in cycle I increased to 74.86 with completeness of learning $72.22 \%$ and in cycle II increased to 81.94 with completeness of learning reach $100 \%$. The conclusion obtained from this research is that the application of the Creative Problem Solving learning model with powerpoint media can improve the learning achievement of Hindu students in class VII G SMP Negeri 2 Gianyar in the second semester of the 2018/2019 academic year.
\end{abstract}

Keywords: Creative Problem-Solving Learning Model, Powerpoint Media, Learning Achievement.

\section{Pendahuluan}

Pendidikan adalah aspek penting bagi pengembangan sumber daya manusia. Pendidikan juga diyakini mampu menanamkan pengalaman bagi semua orang untuk mempelajari pengetahuan dan keterampilan sehingga dapat diperoleh manusia yang produktif. Salah satu hal yang paling mendasar dalam dunia pendidikan adalah bagaimana usaha untuk menginovasi proses pembelajaran sehingga memperoleh hasil yang maksimal.

\footnotetext{
*Corresponding author.
} 
Guru sebagai ujung tombak pendidikan dan keberhasilan pelaksanaan UU Sistem Pendidikan, diharapkan memiliki pengetahuan dan keterampilan yang berhubungan dengan tugas dan tanggung jawabnya selaku guru yang profesional. Guru yang profesional harus memiliki seperangkat kompetensi (pengetahuan, keterampilan dan perilaku) untuk mampu menjalankan tugas yang diembannya. Berdasarkan UU no. 14 Tahun 2005 tentang Guru dan Dosen pada Bab IV Pasal 10 ayat (1) menyatakan bahwa Kompetensi guru sebagaimana dimaksud dalam Pasal 8 meliputi kompetensi pedagogik, kompetensi kepribadian, kompetensi sosial, dan kompetensi profesional yang diperoleh melalui pendidikan profesi.

Sementara menurut Saud (2012: 50) Proyek Pembinaan Pendidikan Guru (P3G) telah merangkum kompetensi guru di Indonesia yang meliputi: (1) menguasai bahan; mengelola program belajar-mengajar; menggunakan media/sumber belajar; menguasai landasan kependidikan; mengelola interaksi belajar-mengajar; menilai prestasi belajar; mengenal fungsi dan layanan bimbingan penyuluhan; mengenal dan menyelenggarakan administrasi sekolah; dan memahami dan menafsirkan hasil penelitian guna keperluan pengajaran.

Sementara itu, Ali Idrus menyatakan untuk menghadapi tantangan zaman dengan kemajuan teknologi informasi dan ilmu pengetahuan yang serba cepat dibutuhkan guru profesional yang intelektual dan bermoral. Hal itu sesuai dengan pendapat Giroux (1988) yang disampaikannya bahwa sosok guru yang mampu memunculkan inovasi dalam pendidikan adalah guru yang menurutnya mau terus berkembang dan belajar seumur hidup, tidak pernah puas dengan apa yang dimengerti, mau membawa perubahan, berpikir kritis, rasional bebas mengembangkan pikiran, reflektif, berani membela kebenaran dan keadilan. Dan tidak dibutuhkan guru yang hanya mempertahankan status quo-nya dan menjalankan tugasnya seperti tukang (Idrus, 2009: 157).

Menyadari permasalahan yang sedang dihadapi, untuk mendukung semua yang telah dijelaskan di atas. Guru selaku peneliti yang bertugas di SMP Negeri 2 Gianyar mencoba melakukan koreksi dan refleksi atas prestasi belajar awal siswa kelas VII G semester II tahun pelajaran 2018/2019 yang ditemukan pada saat observasi. Rata-rata nilai mata pelajaran Agama Hindu siswa yang diperoleh hanya mencapai 68,05 dengan prosentase ketuntasan belajar sebesar $30,55 \%$. Nilai tersebut ternyata masih jauh dari Kriteria Ketuntasan Minimal (KKM) yang ditetapkan sekolah yaitu 75,00.

Pengamatan dan perenungan kembali jalannya proses pembelajaran yang telah dilakukan membuahkan kesimpulan beberapa faktor yang penyebabnya adalah(a) kurang seriusnya guru dalam melakukan persiapan untuk memulai proses pembelajaran; (b) kurangnya daya dukung berupa media/sumber belajar yang dimanfaatkan guru saat pelaksanaan pembelajaran, dan (c) kurangnya daya kreativitas siswa akibat waktu belajar banyak dikuasai guru sehingga ketika usai proses pembelajaran pengetahuan dan pemahaman yang harusnya dikuasai siswa belum tecapai.

Mempertimbangkan kondisi tersebut, guru melakukan konsultasi dengan beberapa teman sejawat dan ditemukan solusi yang menurut pertimbangan guru akan mampu menuntaskan permasalahan yang sedang dihadapi. Solusi tersebut adalah dengan menggunakan model Creative Problem Solving. Model pembelajaran Creative Problem Solving (CPS) merupakan suatu model pembelajaran yang melakukan pemusatan pada pengajaran dan keterampilan pemecahan masalah, yang diikuti dengan penguatan keterampilan (Asikin \& Pujiadi, 2008: 38)

Mengupayakan model pembelajaran berbasis masalah dengan tujuan untuk melatih siswa agar dapat berpikir kreatif dan kritis menghadapi masalah. Dukungan yang disiapkan guru untuk mewujudkan hal itu dengan mengupayakan dan memanfaatkan media pembelajaran yang mampu menarik minat dan konsentrasi mereka untuk belajar. Hal itu dilakukan mempertimbangkan apa yang disampaikan (Darmawan, 2009: 66) yang mengkaji tentang media, model pembelajaran, dan perilaku belajar peserta didik, dengan pernyataan bahwa peranan teknologi informasi dan komunikasi dalam mengemas informasi pembelajaran akan memperkuat stimulus dalam proses pembelajaran. Dengan stimulus ini pembelajar akan mampu mengoptimalkan perilaku belajarnya.

Dasar kajian inilah yang kemudian dijadikan landasan guru untuk melakukan pembuktian sendiri dalam proses pembelajaran yang dilakukan, sejauh mana model 
pembelajaran yang dilaksanakan secara kreatif dengan media pembelajaran yang bertumpu pada kemajuan teknologi informasi dapat meningkatkan prestasi belajar siswa

Adapun langkah yang diambil untuk memperbaiki prestasi belajar siswa yaitu dengan tindakan perbaikan yang selanjutnya disusun dalam bentuk penelitian tindakan kelas. Dengan cara ini diharapkan peserta didik akan tertarik untuk berinteraksi dalam pembelajaran sehingga akan meningkatkan kemampuan dan keterampilannya.

\section{Metode Penelitian}

Penelitian ini dilaksanakan di SMP Negeri 2 Gianyar yang beralamat di Jalan Dauh Uma, Bitra, Gianyar. Penelitian yang dilakukan termasuk penelitian tindakan. Oleh karenanya, rancangan yang khusus untuk sebuah penelitian tindakan sangat diperlukan. Peningkatan diri untuk hal yang lebih baik ini dilakukan terus menerus sampai tujuan tercapai Arikunto et al., (2016). Untuk penelitian ini penulis memilih rancangan penelitian tindakan yang disampaikan oleh Arikunto (2010) seperti terlihat pada gambar berikut.

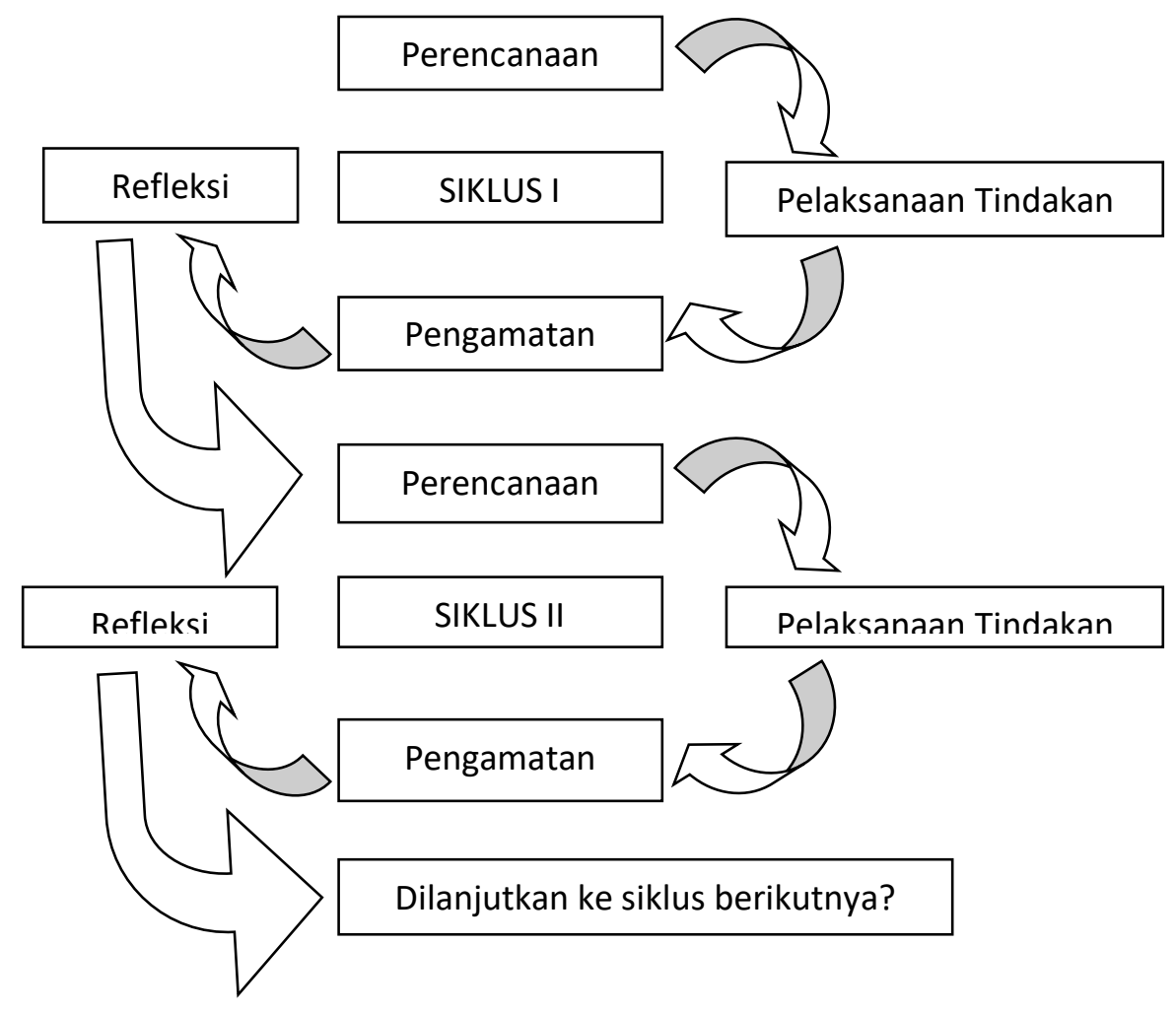

(Arikunto, 2010)

Gambar 1. Gambar Rancangan Penelitian Tindakan Kelas

\section{Siklus I}

Berdasarkan bagan, tahapan kegiatan penelitian dapat dijelaskan sebagai berikut:

\section{Perencanaan Tindakan}

Adapun perencanaan yang dilakukan untuk melaksanankan penelitian tindakan kelas adalah sebagai berikut.

1) Berkoordinasi dengan kepala sekolah untuk melaksanakan penelitian

2) Melakukan refleksi awal dengan melihat prestasi belajar Agama Hindu siswa sebelum dilaksanakan penelitian.

3) Melakukan analisis kurikulum untuk mengetahui standar kompetensi, kompetensi dasar dan menyusun silabus yang disampaikan kepada siswa dengan menggunakan model pembelajaran Creative Problem Solving dengan media powerpoint. 
4) Menyusun Rencana Pelaksanaan Pembelajaran (RPP) dilengkapi LKS yang dirancang. Langkah-langkah pembelajarannya diarahkan pada model pembelajaran Creative Problem Solving dengan media powerpoint untuk materi yang diajarkan.

5) Menyusun lembar penilaian dan tes/evaluasi berupa tes prestasi belajar dan kuesioner motivasi belajar.

6) Membuat ringkasan materi yang dibahas.

7) Membuat instrumen untuk penelitian tindakan kelas berupa lembar refleksi.

2. Pelaksanaan Tindakan

Dalam pelaksanaan ini disusun sesuai dengan tahap pelaksanaan penerapan model pembelajaran Creative Problem Solving dengan media powerpoint dalam mata pelajaran Agama Hindu untuk mengetahui prestasi belajar siswa. Pada setiap siklus penelitian terdiri dari 4 kali pertemuan. 3 kali pertemuan untuk melaksanakan proses pembelajaran dan 1 kali pertemuan untuk melaksanakan evaluasi atau tes prestasi belajar dan mengukur motivasi belajar siswa. Langkah-langkahnya adalah sebagai berikut.

1) Persiapan pada awal pembelajaran

Pada tahap ini, kegiatan yang dilaksanakan adalah mempersiapkan perangkat pembelajaran, membentuk kelompok learning komunity, menetukan skor awal, mengatur tempat duduk dan melakukan kegiatan apersepsi.

2) Pelaksanaan pembelajaran

Langkah-langkah dalam pelaksanaan tindakan ini adalah dilaksanakan sesuai dengan Rencana Pelaksanaan Pembelajaran (RPP) yang telah disusun dan disiapkan dengan menerapkan tahap-tahap model pembelajaran Creative Problem Solving dengan media powerpoint.

3. Observasi / Evaluasi

Pada pertemuan ke 4, guru melaksanakan tes prestasi belajar dan mengukur motivasi belajar siswa. Kegiatan yang dilakukan pada tahap evaluasi yaitu memberikan lembar tes evaluasi kepada siswa yang bertujuan untuk mengetahui prestasi belajar siswa dan kuesioner motivasi belajar untuk mengetahui tingkat motivasi belajar siswa setelah dilaksanakannya pembelajaran dengan model pembelajaran Creative Problem Solving dengan media powerpoint. Hasil evaluasi akan menjadi acuan bagi peneliti dalam merancang pembelajaran pada siklus berikutnya (siklus II).

4. Refleksi

Refleksi ini dilakukan untuk melihat dan mengkaji hasil tindakan pada siklus I mengenai prestasi belajar Agama Hindu dan motivasi belajar siswa. Hasil kajian tindakan siklus I ini, selanjutnya dipikirkan untuk dicari dan ditetapkan beberapa alternatif tindakan baru yang diduga lebih efektif untuk meningkatkan prestasi belajar Agama Hindu. Alternatif tindakan ini ditetapkan menjadi tindakan baru pada rencana tidakan dalam penelitian.

Metode yang digunakan untuk menganalisis data hasil penelitian ini adalah metode deskriptif. Untuk data kuantitatif dianalisis dengan mencari mean, median, modus, membuat interval kelas dan melakukan penyajian dalam bentuk tabel dan grafik.

1. Rata-rata (mean) dihitung dengan:

Jumlah nilai

Jumlah siswa

2. Median (titik tengahnya) dicari dengan mengurut data/nilai siswa dari yang terkecil sampai terbesar. Setelah diurut apabila jumlah data ganjil maka mediannya adalah data yang di tengah. Kalau jumlahnya genap maka dua data yang di tengah dijumlahkan dibagi 2 (dua).

3. Modus (angka yang paling banyak/paling sering muncul) setelah diasccending/diurut angka tersebut

4. Untuk persiapan penyajian dalam bentuk grafik maka hal-hal berikut dihitung terlebih dahulu. 
1. Banyak kelas $(K)=1+3,3 \times \log (N)$

2. Rentang kelas $(r)=$ skor maksimum - skor minimum

3. Panjang kelas interval (i) $=\frac{r}{K}$

Indikator keberhasilan penelitian yang diusulkan dalam penelitian ini pada siklus I dan siklus II mencapai nilai rata-rata minimal 75,00 dengan ketuntasan belajar minimal $85 \%$.

\section{Hasil Dan Pembahasan}

Model CPS (Creative Problem Solving) adalah suatu model pembelajaran yang melakukan pemusatan pada pengajaran dan keterampilan pemecahan masalah, yang diikuti dengan penguatan keterampilan. Ketika dihadapkan dengan suatu pertanyaan, siswa dapat melakukan keterampilan memecahkan masalah untuk memilih dan mengembangkan tanggapannya. Tidak hanya dengan cara menghafal tanpa dipikir, keterampilan memecahkan masalah memperluas proses berpikir (Pepkin, 2004:1). Adapun proses dari model pembelajaran CPS, terdiri atas klarifikasi masalah, pengungkapan pendapat, evaluasi dan pemilihan, dan implementasi. Dengan membiasakan siswa menggunakan langkah-langkah yang kreatif dalam memecahkan masalah, diharapkan dapat membantu siswa untuk mengatasi kesulitan dalam belajar. Penggunaan model pembelajaran CPS ini diharapkan dapat menimbulkan minat sekaligus kreativitas dan motivasi siswa dalam mempelajari setiap materi pelajaran, sehingga siswa dapat memperoleh manfaat yang maksimal baik dari proses maupun prestasi belajarnya (Supardi dan Putri, 2010).

Penerapan model pembelajaran CPS akan lebih efektif lagi diterapkan menggunakan media powerpoint. Media powerpoint merupakan suatu software yang akan membantu dalam menyusun sebuah persentase yang efektif, profesional, dan juga mudah. Powerpoint akan membantu sebuah gagasan menjadi lebih menarik dan jelas tujuannya jika dipersentasikan karena powerpoint akan membantu dalam pembuatan slide, outline persentase, persentase elektronika, menampilkan slide yang dinamis, clip art yang menarik, yang semua itu mudah ditampilkan di layar monitor komputer.

Berdasarkan hasil tes prasiklus didapatkan perolehan nilai rata-rata kelas prestasi belajar Agama Hindu masih sangat rendah, yaitu dengan perolehan skor nilai secara klasikal yaitu 2450 dan rata rata hanya mencapai 68,05 , dimana siswa yang mencapai persentase ketuntasan belajar $30,55 \%$, dan yang tidak mencapai ketuntasan adalah 69,44\%, dengan tuntutan KKM untuk mata pelajaran Agama Hindu di kelas VII G SMP Negeri 2 Gianyar adalah dengan nilai 75,00.

Pada siklus I sudah diupayakan untuk perbaikan pembelajaran untuk meningkatkan prestasi belajar Agama Hindu dengan menggunakan model pembelajaran Creative Problem Solving dengan media powerpoint. Peneliti telah giat melakukan kegiatan yang susuai dengan kebenaran teori yang ada sehingga peneliti memperoleh hasil yang lebih baik dari proses awal, yaitu dengan rata rata nilai 74,86 dari jumlah nilai 2695 seluruh siswa di kelas VII G SMP Negeri 2 Gianyar, dan prosentase ketuntasan belajarnya adalah $72,22 \%$, yang tidak tuntas adalah $27,77 \%$. Hasil ini belum maksimal, karena belum mecapai indikator keberhasilan penelitian yang mencanangkan dengan minimal prosentase ketuntasan belajar $85,00 \%$.

Dengan tindakan yang sangat maksimal dan pelaksanaan yang betul-betul mengikuti kebenaran teori sesuai dengan model pembelajaran Creative Problem Solving dengan media powerpoint dalam pembelajaran Agama Hindu di kelas VII G SMP Negeri 2 Gianyar, dimana hasil yang diperoleh pada siklus II ini ternyata prestasi belajar Agama Hindu meningkat secara signifikan dengan nilai rata-rata 81,94, dan ketuntasan belajarnya adalah $100 \%$.

Semua hasil yang diperoleh dari awal, siklus I dan siklus II digambarkan dalam bentuk tabel dan grafik seperti berikut. 
Tabel 01 : Tabel Data Prestasi Belajar Siswa Kelas VII G SMP Negeri 2 Gianyar

\begin{tabular}{cccc}
\hline DATA & AWAL & SIKLUS I & SIKLUS II \\
\hline Rata Rata Kelas & 68,05 & 74,61 & 81,94 \\
Persentase Ketuntasan & $30,55 \%$ & $72,22 \%$ & $100 \%$ \\
\hline
\end{tabular}

Hasil penelitian ini sejalan dengan hasil penelitian yang dilakukan oleh Suparmi (2018) dengan judul Efektivitas Penggunaan Model Pembelajaran Creative Problem Solving Dengan Metode Drill Untuk Meningkatkan Kemampuan Menyimak Dialog Interaktif Dalam Pembelajaran Bahasa Indonesia. Dalalm penelitiannya dinyatakan bahwa penerapan model pembelajaran Creative Problem Solving dengan Metode Drill dapat meningkatkan prestasi belajar siswa dalam menyimak dialog interaktif pada pembelajaran Bahasa Indonesia.

\section{Simpulan}

Berdasarkan penelitian yang telah dilakukan, ditemukan dari data awal ada 25 siswa mendapat nilai dibawah KKM dan pada siklus I menurun menjadi 10 siswa dan siklus II tidak ada siswa mendapat nilai di bawah KKM. Nilai rata-rata awal 68,05 naik menjadi 74,86 pada siklus I dan pada siklus II naik menjadi 81,94. Dari data awal siswa yang tuntas hanya 11 orang sedangkan pada siklus I menjadi lebih banyak yaitu 26 siswa dan pada siklus II sebanyak 36 siswa. Paparan di atas membuktikan bahwa model pembelajaran Creative Problem Solving dengan media powerpoint dapat memberi jawaban sesuai tujuan penelitian ini, yaitu penggunaan model pembelajaran Creative Problem Solving dengan media powerpoint mampu meningkatkan prestasi belajar Agama Hindu siswa kelas VII G semester II SMP Negeri 2 Gianyar tahun pelajaran 2018/2019..

\section{Daftar Pustaka}

Arikunto Suharsimi, Suhardjono, Supardi.2006. Penelitian Tindakan. Kelas. Jakarta: Bumi Aksara.

Arikunto, S. 2010. Prosedur Penelitian Suatu Pendekatan Praktik. Jakarta: Rineka Cipta.

Asikin dan Pujiadi. Lembaran IImu Kependidikan Jilid 37, NO. 1, Juni 2008. Pengaruh Model Pembelajaran Matematika Creative Problem Solving (CPS) Berbantuan CD Interaktif Terhadap Kemampuan Pemecahan Masalah Pada Siswa Kelas X SMA Negeri 1 Semarang. FMIPA Unnes.

Darmawan, E. 2009. Ruang Publik dalam Arsitektur Kota. Semarang: Badan Penerbit UNDIP. Idrus, M. 2009. Metode penelitian IImu Sosial. Yogyakarta: PT. Gelora Akasara.

Pepkin, K. L. 2004. Creative Problem Solving in Math. http://www.uh.edu/hti/ cu/2004/v02/04. htm (Diakses 10 Maret 2014).

Rahman, B. 2009.Skripsi.Perbandingan Kemampuan Koneksi Matematik Siswa yang Pembelajarannya Menggunakan Model Creative Problem Solving (CPS) dengan Siswa yang Pembelajarannya Menggunakan Model Konvensional. FPMIPA UPI. Bandung.

Saud, Udin Syaefudin. 2012. Pengembangan Profesi Guru. Bandung: Alfabeta.

Supardi dan Putri. 2010. Penelitian Tindakan Kelas. Jakarta: PT Bumi Aksara.

Suparmi, Nyoman. 2018. Efektivitas Penggunaan Model Pembelajaran Creative Problem Solving Dengan Metode Drill Untuk Meningkatkan Kemampuan Menyimak Dialog Interaktif Dalam Pembelajaran Bahasa Indonesia. Jurnal IImiah IImu Sosial Undiksha Volume 4 Nomor 2. 